\title{
Immune Response to Koi Herpesvirus (KHV) of Koi and Koi $\times$ Red Common Carp (Cyprinus carpio)
}

\author{
Ju-ae Hwang, Jung Eun Kim, Hyeong-su Kim and †'Jeong-Ho Lee \\ Inland Aquaculture Research Center, National Institute of Fisheries Science (NIFS), Changwon 51688, Korea
}

\begin{abstract}
Koi herpesvirus (KHV), also known as Cyprinid herpes virus 3 (Cyprinid 3) is lethal disease in common carp and koi (Cyprinus carpio). Two different groups (KK and RK) were infected KHV by intraperitoneal injection. Fish for gene expression analysis were sampled at $0 \mathrm{~h}, 12 \mathrm{~h}, 24 \mathrm{~h}, 48 \mathrm{~h}$ and $72 \mathrm{~h}$ post infection (p.i). The results showed that two immune related gene, Interferons (INFs) a $\beta$ and Interleukin (IL)-12 p35 induced a high response in RK. The IL-12 p35 cytokine and Toll-like receptor (TLR) 9 were significantly high expressed on $48 \mathrm{~h}$ post infection (p.i) in RK as compared to the KK. The histopatological examination reveals focal necrosis in liver and infiltrate of lymphocytes in spleen of KK as compared to the RK. In immunohistochemistry analysis, the KHV protein high expressed in the infected kidney cell and slenocyte of KK. Therefore, the expression of IL-12 p35, IFN a $\beta$ and TLR 9 may provide a potentially genes related with KHV resistance in Koi and red common carp $\times$ koi.
\end{abstract}

Key words : Koi (Cyprinus carpio), Red common carp (Cyprinus carpio), KHV, IFNs, IL-12, TLR

\section{INTRODUCTION}

Within the last decade, mas mortality of farmed carp and koi (Cyprinus carpio) has been observed and spread in Europe and in Asia (Hedrick et al., 2000; Sano et al., 2004; Bondat-Reantaso et al., 2007; Gomez et al., 2011). The disease-causing virus has been identified as Cyprinid herpesvirus-3 (CyHV-3) (Waltzek et al., 2005) also known as Koi Herpesvirus (KHV) (Hedrick et al., 2000). CyHV-3 is a member of a family Alloherpesviridae comprising piscine and amphibian herpes viruses, as proposed by McGeoch et al. (2006). The clinical symptoms of disease caused by CyHV-3 are: hyperplasia and necrosis of the respiratory epithelium of the gill (Hedrick et al., 2000; Neukirch \& Kunz., 2001), and focal necrosis of hepatocytes in the liver and glomerular cells in the kidney (Hedrick et al., 2000).

Several groups have been reported to establish a control and prevention for the KHV disease. An effective and safe vaccine is not currently available and Chemotherapy is not applicable. Vaccination is affective in intensive culture system but most of traditional aquaculture system is carried out in semi-intensive system or recirculation aquaculture system. Moreover, use of a vaccine that are available in only Israel. Alternatively, resistance breeding to KHV has been shown among different carp strains (Shapira et al., 2005; Dixon et al., 2009). Selection for carp lines can be used to improve growth and disease Resistance (Dixon et al., 2009). It has been shown that hybrid crosses of common carp were less sensitive to desease than their parental groups (Hines et al., 1974). Previous studies proposed cross-

\footnotetext{
Manuscript received October 10, 2017, Received in revised form December 8, 2017, Accepted December 13, 2017

${ }^{\dagger}$ Corresponding Author : Jeong-Ho Lee, National Institute of Fisheries Science, NIFS, Changwon 51688, Korea. Tel: +82-55-540-2780, Fax: +82-55-5466292, E-mail: jhlee7124@korea.kr

This is an Open Access article distributed under the terms of the Creative Commons Attribution Non-Commercial License (http:// creativecommons.org/licenses/by-nc/3.0) which permits unrestricted non-commercial use, distribution, and reproduction in any medium, provided the original work is properly cited.
} 
breeding as a potential method to improve fish resistance to KHV disease (Shapira et al., 2005; Hedrick et al., 2006). Also, in a previous study from our group show that the improvement of survival rate during the KHV infection in koi and red common carp breeding group (not published data). Host defense against KHV infections includes activation of innate and adaptive immune response. Cytokines associated with adaptive immunity are included for Interleukin (IL) -2, Interferons (IFNs), IL4/13, IL-10 and TGF$\beta$ 1. IFNs are secreted proteins (cytokine) that induce an antiviral state in cells and the defense against virus infection (Samuel, 2001). In fish, the virus induced interferons are appear to be analogues of mammalian type 1 IFNs (Aggad et al., 2009). An activation of the type I IFN production in carp cells interferes with the development of a CyHV-3 infection (Adamek et al., 2012). IL-12 is produced primarily by antigen presenting cells (APC), such as macrophages and dendritic cells and following detection of pathogens via pattern recognition receptors such as Tolllike receptors (TLRs) (Watford et al., 2003; Trinchieri, 2003; Zhang \& Wang, 2008). Type I IFNs and IL-10a and IL-10b for resistance to the KHV induced disease were analyzed in carp lines (Kongchum et al., 2010, 2011). However, information of immune response and susceptibility of koi and koi $\times$ red common carp (Cyprinus carpio) to the KHV remains to be unclear. Therefore, the present study deals with immune response of important genes for KHV infection on different cross breeding in Koi and Red common carp (Cyprinus carpio).

\section{MATERIALS AND METHODS}

\section{Experimental Fish and KHV virus infection}

Two strains of koi and red common carp (Cyprinus carpio) were used in this study. The breeding for koi(Cyprinus carpio) and red common carp(Cyprinus carpio) was conducted at the Inland Aquaculture Research Center, National Institute of Fisheries Science, Changwon, Korea. The
Breeding experiments of cultivated koi were purchased from a local fish farm from the Gyeonggi region. In the spring, sexually mature breeders without any disease were selected for production of families. 12 females (mean weight $2.5 \pm 0.5 \mathrm{~kg})$ and 12 males $(1.8 \pm 0.4 \mathrm{~kg})$ Ovulated eggs of koi were stripped and fertilized with sperm from koi and red common carp. Fish were used for the virus infection at the age of 10 months, when they weighed 10 $12 \mathrm{~g}$. After a 2 week adaptation in a re-circulation tank at $24^{\circ} \mathrm{C}$, the fish were used for infection trials. Experiments were performed in triplicate aquaria with 3 groups: KK (koi $\times$ koi) and RK (red common carp $\times$ koi), and uninfected KK (control). There were 150 fish per group (total of 600 fish). Fish were infected by intraperitoneal injection, and kept at $24^{\circ} \mathrm{C}$, and the control group was treated with saline. Fish were fed on a pellet diet and the tissue samples (kidney, liver and spleen) were collected from o h, 12 h, 24 $\mathrm{h}, 48 \mathrm{~h}, 72 \mathrm{~h}$ during KHV infection and preserved at $-80^{\circ} \mathrm{C}$ until RNA extraction. In addition, blood was collected on day 3 post infection (p.i.) for haematological changes analysis. Smears were prepared, air dried, and Giemsa stained for the cell count and morphologic examination.

\section{Virus}

The KHV strain F347 (VR-1592) was purchased from American Type Culture Collection (ATCC). The virus was incubated in common carp brain (CCB) cells. The CCB cell line was maintained at $23{ }^{\circ} \mathrm{C}$ in minimum essential medium (MEM, Sigma, Germany) and supplemented with $10 \%$ fetal bovine serum (FBS, Sigma, Germany), 2 mM L-glutamine, $100 \mathrm{IU} \mathrm{mL}{ }^{-1}$ penicillin, and $100 \mu \mathrm{g} \mathrm{mL}^{-1}$ streptomycin (Sigma, Germany) for 14 days. The presence of CyHV-3 was evaluated by the presence of characteristic cytopathic effects and was confirmed by PCR (Gilas et al. 2002). After titration, the virus was adjusted to a final concentration of $10^{4} 50 \%$ tissue culture infectious dose (TCID50) per $\mathrm{mL}^{-1}$. 


\section{Histological observation}

For histopathology and IHC (Immunohistochemistry), kidneys, liver and spleen were collected from each group on days 3 and fixed in 4\% neutral formalin for $24 \mathrm{~h}$. Paraffin-embedded tissues were stained with hematoxylin and eosin (H\&E) for histological observation, and analyzed by IHC staining. For IHC, heat-induced antigen retrieval was performed using $0.01 \mathrm{M}$ sodium citrate buffer in a microwave for $15 \mathrm{~min}$. After quenching of endogenous peroxidase and blocking in 3\% goat serum, tissue was incubated with the primary monoclonal anti-KHV antibody (P14, Aquatic Diagnostic Ltd.). After three washes with Trisbuffered saline (TBST), followed by addition of the secondary antibody (goat anti-mouse $\operatorname{IgG}$ ) peroxidase activity was detected with 32-diaminobenzidine-tetrahydrochloride (DAB, Abcam). To investigate the specificity of these reactions, negative and positive controls were used. Finally, the samples were examined under optical microscopy (AxioCam MR, Carl Zeiss, Germany).

\section{RNA preparation and PCR}

Each sample was homogenized in Trizol Reagent (Invitrogen) using a motorized Kontes RNase-Free Pellet Pestle Grinder, a disposable nuclease-free plastic pestle and a 1.5 $\mathrm{mL}$ microcentrifuge tube, as per manufacturer's instructions, and suspended in DEPC-treated water for RT-PCR. Total RNA integrity was verified by $1.2 \%$ agarose gel electrophoresis, and purity was assessed by A260/280 and A260/230 NanoDrop UV spectrophotometry for both the crude and column purified RNA extracts. cDNA synthesis was used for reverse transcribed into cDNA using First Strand cDNA synthesis kit (Roche). The gene specific primers are listed in Table 1. KHV DNA was detected using the CyHV-3-specific PCR procedure described by Gilas et al. (2002). DNA was extracted from gills using Qiagen DNeasy Blood \& Tissue kit, and PCR amplification was performed using specific primers (Table.1) for the CyHV-3 TK and Sph I-5 gene (OIE, 2013). The PCR products were subjected to electrophoresis in an agarose

Table 1. Primer used in the present study

\begin{tabular}{|c|c|c|c|}
\hline \multicolumn{4}{|c|}{ KHV detection } \\
\hline Primer & Sequence & Reference & Product size (bp) \\
\hline TK F & 5'-GGGTTACCTGTACGAG-3' & \multirow{2}{*}{ OIE (2013) } & \multirow{2}{*}{409} \\
\hline TK R & 5'-CACCCAGTAGATTATGC-3' & & \\
\hline SphI-5 F & 5'-GACACCACATCTGCAAGGAG-3' & \multirow{2}{*}{ OIE (2013) } & \multirow{2}{*}{292} \\
\hline SphI-5 R & 5'-GACACATGTTACAATGGTCGC-3' & & \\
\hline \multicolumn{4}{|c|}{ Real time PCR } \\
\hline Primer & Sequence & \multicolumn{2}{|c|}{ Accession No. } \\
\hline IL-12p35 F & 5'-TGCTTCTCTGTCTCTGTGATGGA-3' & \multirow{2}{*}{\multicolumn{2}{|c|}{ AJ580354 }} \\
\hline IL-12p35 R & 5'-CACAGCTGCAGTCGTTCTTGA-3' & & \\
\hline INF a $\beta$ F & 5'-GGCAGATATGGGACGGTGAG-3' & \multirow{2}{*}{\multicolumn{2}{|c|}{ EC393381 }} \\
\hline INF a $\beta$ R & 5'-GTCCTCCACCTCAGCTTTGTC-3' & & \\
\hline TLR $9 \mathrm{~F}$ & 5'-GGAGACCACTCTGTTTGGAAG-3' & \multirow{2}{*}{\multicolumn{2}{|c|}{ GU809229 }} \\
\hline TLR $9 \mathrm{R}$ & 5'-CGGCATCGTTCTTGTTGTC-3' & & \\
\hline$\beta-\operatorname{actin} F$ & 5'-TCACACCACAGCCGAGAG-3' & \multirow{2}{*}{\multicolumn{2}{|c|}{ M24113 }} \\
\hline$\beta-\operatorname{actin} \mathrm{R}$ & 5'-CAGGGAGGAGGAGGAAGCAG-3' & & \\
\hline
\end{tabular}


gel (1\%), visualized by UV transillumination, and photographed.

\section{Quantitative real time PCR analysis}

Real-time quantitative reverse transcriptase PCR(RTqPCR) was used for an expression analysis of immune related gene. Real-time PCR reaction mixture contained 1 $\mu \mathrm{L}$ of dilutedcDNA sample, specific primer and the Power SYBR Green PCR Master Mix (Applied Biosystems). The reactions for the amplification of each genes was subjected to an initial denaturation at $95^{\circ} \mathrm{C}$ for $15 \mathrm{sec}$, annealing at $60^{\circ} \mathrm{C}$ for $1 \mathrm{~min}$, and elongation at $60^{\circ} \mathrm{C}$ for $30 \mathrm{sec}$. Thermal cycling and fluorescence detection were conducted using the 7500 Real-Time PCR system (Applied Biosystems). Expression of both genes was normalized to an endogenous reference $\beta$-actin and presented as subtraction of target $\mathrm{CT}$ values from $\beta$-actin $\mathrm{CT}$ values ( $\Delta \mathrm{CT}$ value). Comparison of gene expression between groups and calibrator was derived from subtraction of the calibrator $\Delta \mathrm{CT}$ values from the target $\Delta \mathrm{CT}$ values to give a $\Delta \Delta \mathrm{CT}$ value, and relative gene expression was calculated to determine fold difference $(2-\Delta \Delta \mathrm{CT})$. The data were analyzed by oneway ANOVA using the SPSS statistical package (SPSS 5.0; SPSS Inc., USA). Means were separated using Duncan's multiple range test and were considered different at $P<0.05$.

\section{RESULTS}

For the examine of immune response, the Koi herpes (KHV) was adjusted to a final concentration of $10^{4} 50 \%$ tissue culture infectious dose (TCID50) per $\mathrm{mL}^{-1}$ for intraperitoneal injection in order to mating groups $(\mathrm{KK}$; koi $\times$ koi and RK ; red common carp $\times$ koi), and next the presence of KHV was confirmed by PCR (Gilad et al., 2002) in kidney and spleen on day 3 p.i. Fig. 1 shows the all samples (Kidney and spleen) from infected by KHV were positive by PCR. sample from the controls were negative for KHV DNA. In this study, expression of immune-related genes were determined in kidneys collected from KK and

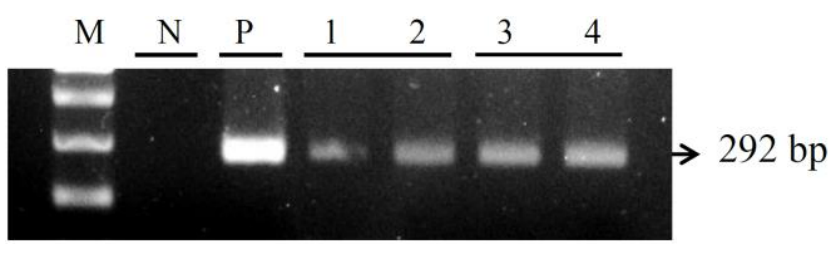

Fig. 1. PCR results of the kidney and spleen samples from infected fish with KHV. Lane M; 100 bp DNA ladder, lane $\mathrm{N}$; negative, lane $\mathrm{P}$; positive, lanes 1-2; Kidney, 3-4; Spleen.

RK during KHV infection. Target genes were standardized using reference gene $\beta$-actin (GeneBank accession no. M24113) for mRNA study. The expression pattern of the IFN a $\beta$, IL-12 p35 and TLR 9 genes were investigated 12 h $24 \mathrm{~h}, 48 \mathrm{~h}$ and $72 \mathrm{~h}$ using real time PCR. IFN a $\beta$ gene expression revealed no significant difference and there was expressed at high levels in the kidney of RK (1.29-fold) compare with the KK (0.83-fold) on $48 \mathrm{~h}$. Also, expression on $72 \mathrm{~h}$ was slightly decreased with a little difference and there was no statistical difference in between $\mathrm{KK}(0.48$-fold $)$ and RK(0.775-fold) (Fig. 2). IL-12 p35 was expressed at significantly higher levels in RK $(P<0.05)$ on $48 \mathrm{~h}$ KHV infection compared with KK (23.89- and 0.99-fold higher than in RK) (Fig. 3). At $48 \mathrm{~h}$ after KHV infection, IL-12 in RK was at 10 -fold increased compared to $24 \mathrm{~h}$. IL-12 is

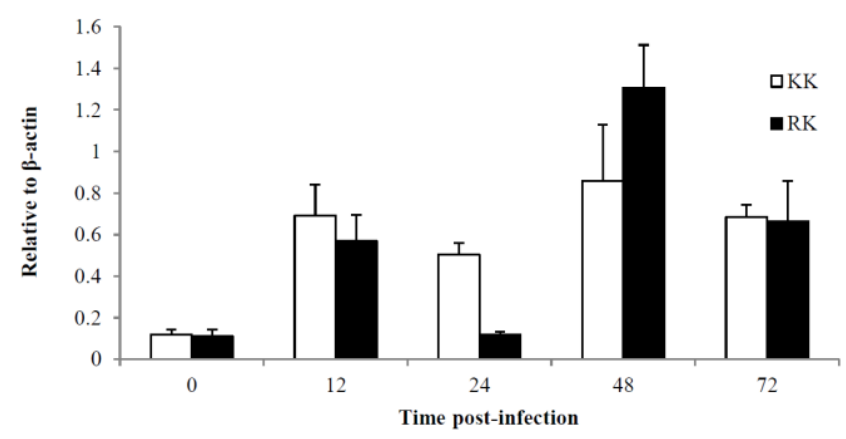

Fig. 2. Expression of IFN $\alpha \beta$ in Kidney from infected fish with KHV. A quantitative real time PCR analysis was performed with equal amounts of total RNA from the kidney from the different groups. $\beta$-actin was used as an internal control. KK; Koi $\times$ koi, RK; Red common carp $\times$ koi. 


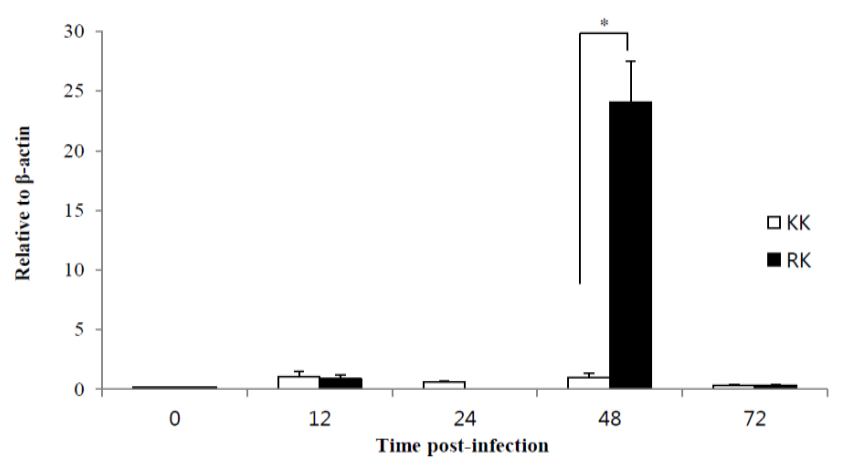

Fig. 3. Expression of IL-12 p35 kidney from infected fish with KHV. A quantitative real time PCR analysis was performed with equal amounts of total RNA from the kidney from the different groups. $\beta$-Actin was used as an internal control. KK; Koi $\times$ koi, RK; Red common carp $\times$ koi. Symbol $(*)$ indicates statistically significant differences at $P<0.05$ between two groups.

produced primarily by antigen presenting cells (APC) such as dendritic cell, macrophage and B cell. Next, blood smears were examined on day 3 with infected. As shown in Figure 5, Haematological change was determined in KK and RK group. In the RK, typically, dendritic cells and macrophage were increased than in the control groups and KK groups. Toll-like receptors (TLRs) have centrol role in innate immunity as they detect virus. The expression of TLR 9 in KK was higher on both $12 \mathrm{~h}$ and $24 \mathrm{~h}$ (0.44-fold and 0.07 -fold higher than in the KK). In contrast, TLR 9

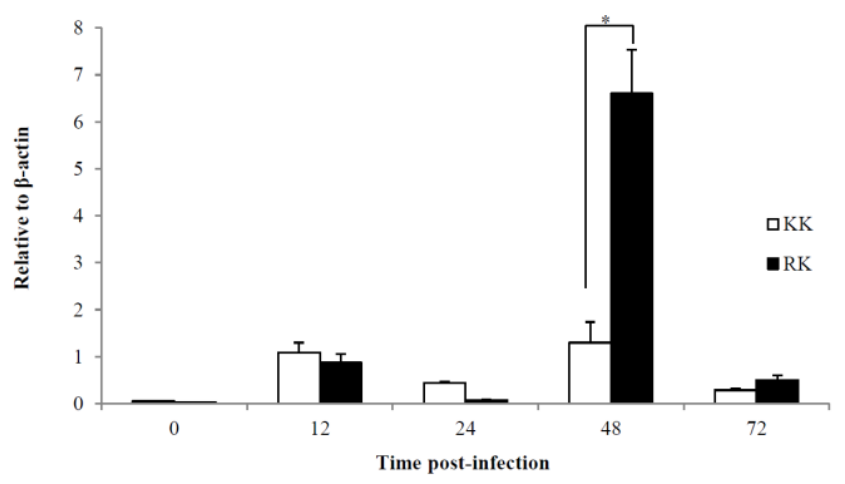

Fig. 4. Expression of TLR 9 kidney from infected fish with KHV. A quantitative real time PCR analysis was performed with equal amounts of total RNA from the kidney from the different groups. $\beta$-Actin was used as an internal control. KK; Koi $\times$ koi, RK; Red common carp $\times$ koi. Symbol(*) indicates statistically significant differences at $P<0.05$ between two groups.

was highly expressed in RK during 48h (1.25- and 6.56fold higher than in RK, $P<0.05$ ) (Fig. 4).

In the infection experiment, clinical signs and mortality started between 3 and 5 p.i. Significant difference in the mortality of fish infected KHV were observed in two groups. The KK group had $72 \%$ survival by day 40 p.i. and the final survival rate was $94 \%$ in the RK group (data not shown). Fig. 6 shows the histopathology of KHV infected liver, spleen and kidney on day 3 p.i. Necrosis of liver in the $\mathrm{KK}$ was more severe than in RK and in the spleen,

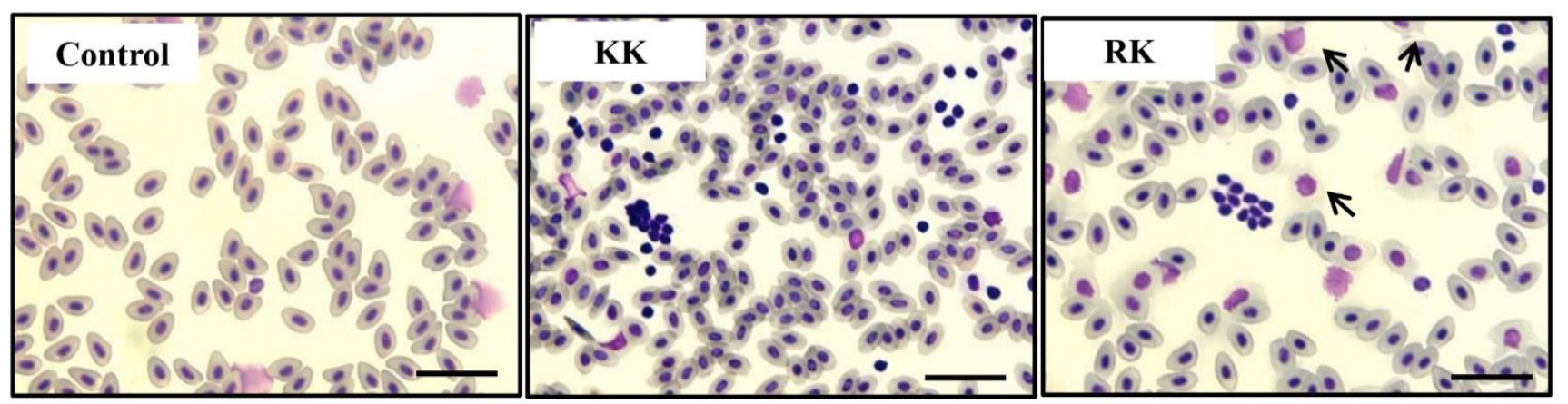

Fig. 5. Haematological changes associated with artificial infection of KHV in different groups. Blood smears were fixed in methanol and Giemsa-stained. Dendritic cells with small protrusions are shown (arrows). Original magnification, $\times 1,000$ (KK; Koi $\times$ Koi, RK; Red common carp $\times$ Koi). Scale bar: $20 \mu \mathrm{m}$. 

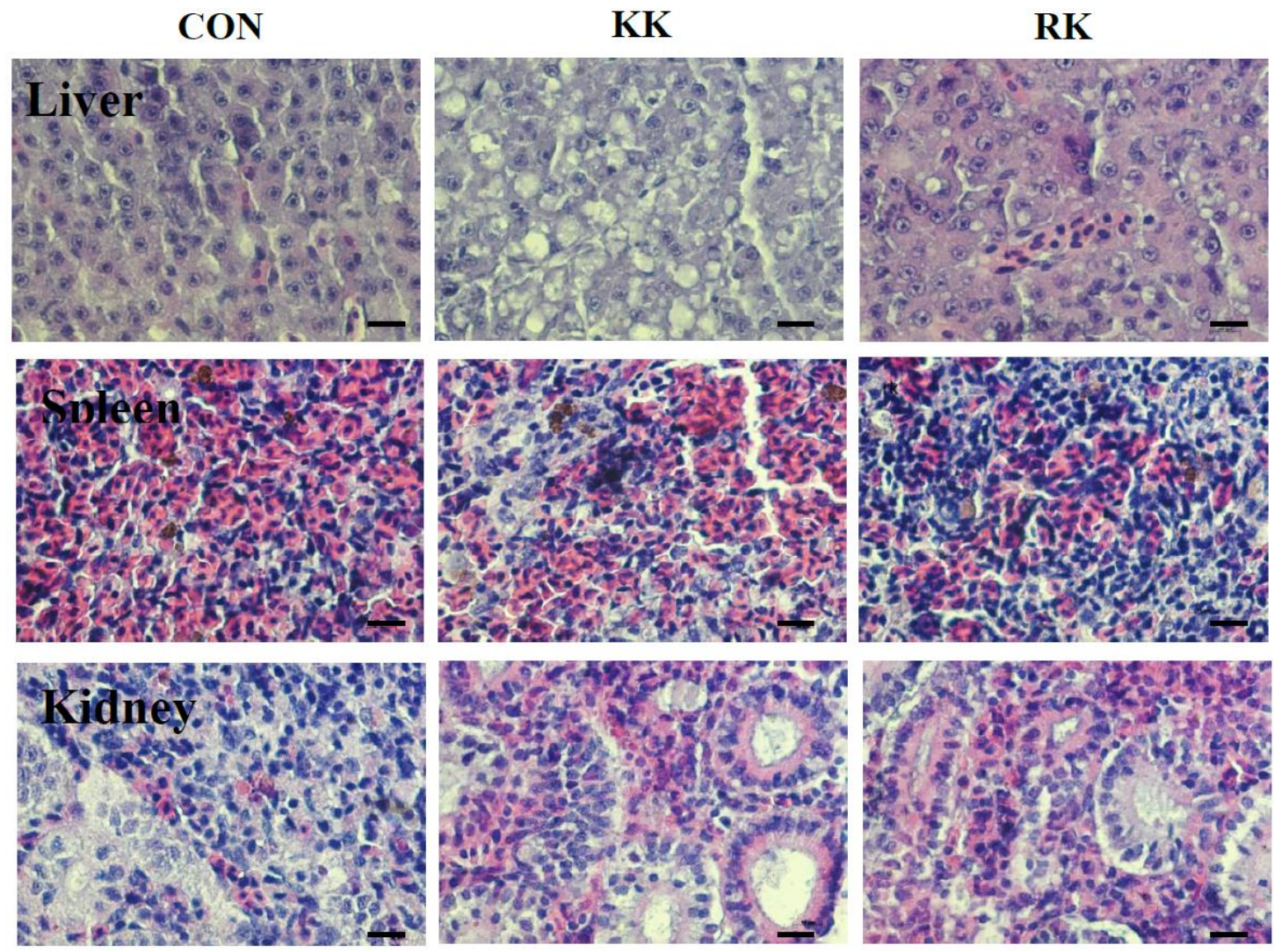

Fig. 6. Histopathological section of the different organs of KHV-infected fish from the different breeding groups. HE staining reveals an inflammatory infiltrate of lymphocytes and polygonal basophilic cells in infected organs (KK; Koi $\times$ koi, RK; Red common carp×koi). Original magnification, 1,000×. Scale bar: $10 \mu \mathrm{m}$.

splenocytes exhibited hyperchromatic nuclei cells. The infected groups showed higher leukocyte (such as lymphocyte and monocyte) and lymphocyte in the spleen of KK than in RK. The hoemopoitic cells in the kidneys were depleted and necrosed. Next, KHV expression was evaluated by immunohistochemistry (IHC). As shown in Fig. 7, the level of expression of KHV was positive in spleen and kidney which was consistent with the KHV expression determined by PCR analysis. The results suggested that the KHV antigen could be abundantly in the cytoplasm and KHV protein was detected more abundant in the KK than in the RK and there was no reactivity in the tissue of control.

\section{DISCUSSIONS}

In this study, we studied the immune response and his- topathology of the two different breeding groups (KK; koi $\times$ koi and RK; red common carp $\times$ koi) infected with KHV. In all vertebrates including fish, type I interferons (IFNs) are essential for the development the innate immune response during the virus infection (Robertsen et al., 2006). However there is very little information about the IFNs response to alloherpesviruses in fish (Adamek et al., 2014). We previously found that different survival rate to KHV infection in two breeding groups (KK and RK) and motality started in KK on day 5. Because of the importance of early host immune response to KHV, we conducted that gene expression during the acute phase of KHV infection. The expression of immune related genes of Koi and red common carp $\times$ koi during the KHV infection showed similar patterns to those previously reported (Adamek et al., 2012; Rakus et al., 2012; Ouyang et al., 2013; Sunarto \& 


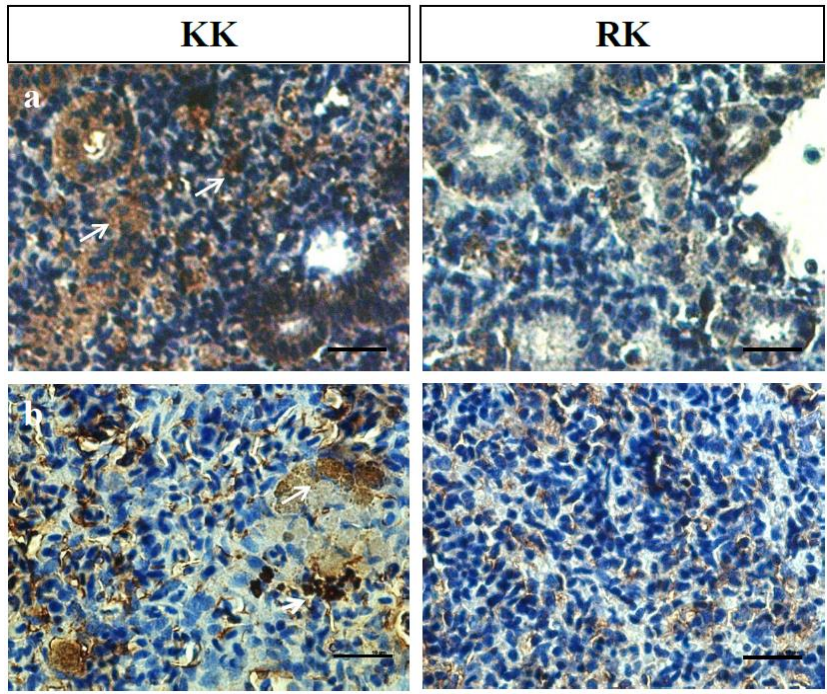

Fig. 7. Immunohistochemistry of KHV infected kidney and spleen at 3 days after infection with KHV (a.kidney, b. spleen). The KHV antigen was present in leukocytes within in the spleen and kidney cells (Arrows). KHV antigen could be abundantly detected in the cytoplasm. Scale bar: $20 \mu \mathrm{m}$.

McColl, 2015). However, Adamek et al. (2013) reported that INF-a2 was up-regulate in infected fish at $24 \mathrm{~h}$ while we observed that expression of INF a $\beta$ was over expressed in RK group at $48 \mathrm{~h}$. IL-12 is pro-inflammatory and prostimulatory cytokine with key role in the development of $\mathrm{T}$ helper (Th) 1 and Th17 cells. IL-12 isoform consisting p35 can induce IFN- $\gamma$ expression in head kidney cells (Wang et al., 2014). In our study, IL-12 p35 and TLR are significantly up-regulated at $48 \mathrm{~h}$ in RK compared KK. In innate immune response, viral DNA was deteceted through TLR 9 in carp and we demonstrated that TLR 9 over expression in the RK. However further information on receptor for KHV DNA will examine. We also observed that the KHV injected group, typically in the RK, showed higher WBC count (data not shown) and an increased dendritic cell (Fig. 5). Considering the role of IL-12 production, It is associated with RT-PCR results. The type I IFN gene expression was associated with differences in susceptibility of the rainbow trout to the infection at 72 hpi (Purcell et al., 2010) and more recent studies on rainbow trout infected with viral haemorrhagic septicaemia virus (VHSV) gave evidence that the rapid induction of a type I IFN is related on the resistance to VHSV (Verrier et al., 2012). In a previous study, the two groups presented difference in survival rate (KK; 76\% and RK; 97\%) which KK group exhibited significantly shorter survival rate than in RK group and also, clinical symptoms seemed correlated with the survival rate. Histological and immunohistochemical analysis have shown that virus induced pathogenic effects in the liver, gill and mainly in the kidney (Pikarsky et al., 2004) and viral protein by the infected kidney cells detected by immunofluorescence on day 3 (Shapira et al., 2005). Kidney and spleen are considered the major and important organs in fish (Rombout et al., 2005) and represent suitable sources for immune cells such as macrophage and lymphocyte which respond to viral infection (Rakus et al., 2012; Agus \& A. McColl, 2015). Here, we show that the KHV antigen was detected in the spleen and kidney in all infected group on day 3. These results are in accordance with PCR experiments in which the viral DNA was detected as early as 3 days after infected fish (Pikarsky et al., 2004; Shapira et al., 2005). The major histocompatibility complex (MHC) is an important component of immune response and disease resistance and although, there are many studies that MHC diversity and resistance pathogens (Rakus et al., 2009; Li et al., 2011; Zhao et al., 2012). However, this is the fist study of the immune-related gene in Koi and red common carp $\times$ koi to the KHV. Increased resistance of RK to KHV could be associated with increased levels of TLR and IL12 p35 in RK compared to KK. Immune gene expression increased at $48 \mathrm{~h}$ not in the kidney but in the spleen (data not shown). Therefore, these time were most likely responsible for delaying the spread of virus. Nevertheless, currently we are unable to explain how important the type I IFN and IL-12 response is to support a clearing of the KHV virus from the Koi and Red common carp $\times$ koi, thus, there will be addressed in our furthure studies.

Here we report the immune response of Koi and red 
common carp $\times$ koi with infected KHV. IL-12 and TLR genes showed relatively high expression in red common carp $\times$ koi and associated with resistance. This approach can provide more insight into immune-related gene response in Koi and red common carp $\times$ koi against KHV.

\section{ACKNOWLEDGEMENT}

This work was supported by a grant from the National Institute of Fisheries Science (R2017003).

\section{REFERENCES}

Adamek M, Rakus KL, Chyb J, Brogden G, Huebner A, Irnazarow I, Steinhagen D (2012) Interferon type I responses to virus infections in carp cells: In Vitro studies on Cyprinid herpesvirus 3 and Rhabdovirus carpio infections. Fish Shellfish Immunol 33:482-493.

Adamek M, Rakus KL, Brogden G, Matras M, Chyb J, Hirono I, Kondo H, Aoki T, Irnazarow I, Steinhagen D (2014) Interaction between type I interferon and Cyprinid herpesvirus 3 in different genetic lines of common carp (Cyprinus carpio L.). Dis Aquat Org 111: 107-118.

Adamek M, Syakuri H, Harris S, Rakus KL, Brogden G, Matras M, Irnazarow I, Steinhagen D (2013) Cyprinid herpesvirus 3 infection disrupts the skin barrier of common carp (Cyprinus carpio). Vet Microbiol 162: 456-470.

Aggad D,Mazel M, Boudinot P, Mogensen KE, Hamming OJ, Hartmann R, other authors (2009) The two groups of zebrafish virus-induced interferons signal via distinct receptors with specific and shared chains. J Immunol 183:3924-3931.

Aoki T, Hirono I, Kurokawa K, Fukuda H, Nahary R, Eldar A (2007) Genome sequences of three koi herpesvirus isolates representing the expending distribution of an emerging disease threatening koi and common carp worldwide. J Virol 81:5058-5065.

Bondat-Reantaso MG, Sunarto A, Subasinghe RP (2007) Managing the koi herpesvirus disease outbreak in Indonesia and the lessons learned. Dev Biol (Basel) 129: 21-8.

Dixon PF, Joiner CL, Way K, Reese RA, Jeney G, Jeney Z (2009) Comparison of the resistance of selected families of a common carp, Cyprinus carpio L., to koi herpesvirus: preliminary study. J. Fish Dis 32:1035-1039.

Gilad O, Yun S, Andree KB, Adkison MA, Zlotkin A, Bercovier H, Eldar A, Hedrick RP (2002) Initial characteristics of koi herpesvirus and development of a polymerase chain reaction assay to detect the virus in koi, Cyprinus carpio koi. Dis Aquat Org 48:101-108.

Gomez DK, Joh SJ, Jang H, Shin SP, Choresca CH, Han JE, Kim JH, Jun JW, Park SC (2011) Detection of koi herpesvirus (KHV) from koi (Cyprinus carpio koi) broodstock in South Korea. Aquaculture 311: 42-47.

Hedrick RP, Gilad O, Yun S, Spangenberg JV, Marty GD, Nordhausen RW, Kebus MJ, Bercovier H, Eldar A (2000) A herpesvirus associated with mass mortality of juvenile and adult koi, a strain of a common carp. J Aquat Anim Health 12:44-57.

Hedrick RP, Waltzek TB, McDowell TS (2006) Susceptibility of koi carp, common carp, goldfish and goldfish $\times$ common carp hybrids to cyprinid herpesvirus- 2 and herpesvirus-3. J Aquat Anim Health 18:26-34.

Hines RS, Wohlfarth G, Moav R, Hulata G (1974) Genetic differences in susceptibility to two diseases among strains of common carp. Aquaculture 3:187-97.

Kongchum P, Palti Y, Hallerman EM, Hulata G, David L (2010) SNP discovery and development of genetic markers for mapping innate immune response genes in common carp (Cyprinus carpio). Fish \& Shellfish Immunology 29:356-361.

Kongchum P, Sandel E, Lutzky S, Hallerman EM, Hulata G, David L, Palti Y (2011) Association between IL10a single nucleotide polymorphism and resistance 
to cyprinid herpesvirus-3 infection in common carp (Cyprinus carpio). J Aquacult 315:417-421.

Li XS, Liu ZZ, Zhao XJ, Ma XQ, Feng W, Wang CH (2011) Major histocompatibility complex DAB allele polymorphism and its association with resistance/ susceptibility to Aeromonas hydrophila in "whole red" color patterns of Cyprinus carpio var. color. J Fish Sci China 35:1293-1301.

McGeoch DJ, Rixon FR, Davison AJ (2006)Topics in herpesvirus genomics and evolution. Virus Res 117:90104.

OIE (2013) In: Manual of Diagnostic Tests for Aquatic Animals.

Ouyang P, Rakus K, Boutier M, Reschner A, Leroy B, Ronsmans M, Fournier G, Scohy S, Costes B, other authors (2013). The IL-10 homologue encoded by cyprinid herpesvirus 3 is essential neither for viral replication in vitro nor for virulence in vivo. Vet Res 1:44-53.

Pikarsky E, Ronen A, Abramowitz J, Levavi-Sivan B, others (2004) Pathogenesis of acute viral disease induced in fish by carp interstitial nephritis and gill necrosis virus. J Virol 78:9544-9551.

Purcell MK, LaPatra SE, Woodson JC, Kurath G, Winton JR (2010) Early viral replication and induced or constitutive immunity in rainbow trout families with differential resistance to Infectious hematopoietic necrosis virus (IHNV). Fish Shellfish Immunol 28:98-105.

Rakus KL, Irnazarow I, Adamek M, Palmeira L, Kawana Y, Hirono I, Kondo H, Matras M, Steinhagen D, Flasz B, Brogden G, Vanderplasschen A, Aoki T (2012) Gene expression analysis of common carp (Cyprinus carpio L.) lines during Cyprinid herpesvirus 3 infection yields insights into differential immune responses. Dev Comp Immunol 37:65-76.

Rakus KŁ, Wiegertjes GF, Admek M, Siwicki AK, Lepa A, Irnazaro I (2009) Resistance of common carp (Cypprinus carpio L.) to Cyprinid herpesvirus-3 is influenced by major histocompatibility $(\mathrm{MH})$ class II B gene poly- morphism. Fish shellfish Immunol 26:737-743.

Robertsen B (2006) The interferon system of teleost fish. Fish Shellfish Immuol 20:172-191.

Samuel CE (2001) Antiviral actions of interferons Clin Microbiol Rev 14 (4), pp. 778-809

Sano M, Ito T, Kurita J, Yanai T, Watanabe N, Satoshi M, et al. (2004) First detection of koi herpesvirus in cultured common carp Cyprinus carpio in Japan. Fish Pathol 39:165-167.

Shapira Y, Magen Y, Zak T, Ktler M, Hulata G, LevaviSivan B (2005) Differential resistance to koi herpes virus $(\mathrm{KHV}) /$ carp interstitial nephritis and gill necrosis virus (CNGV) among common carp (Cyprinus carpio L.) strains and crossbreds. Aquaculture 245:1-11.

Sunarto A, McColl KA (2015) Expression of immunerelated genes of common carp during cyprinid herpesvirus 3 infection. Dis Aquat Organ 9:127-135.

Trinchieri G (2003) Interleukin-12 and the regulation of innate resistance and adaptive immunity. Nat Rev Immunol 3:133-146.

Tu C, Weng MC, Shiau JR, Lin SY (2004) Detection of koi herpesvirus in koi Cyprinus carpio in Taiwan. Fish Pathol 39:109-110.

Verrier ER, Langevin C, Tohry C, Houel A, others (2012) Genetic resistance to rhabdovirus infection in teleost fish is paralleled to the derived cell resistance status. PLoS ONE 7:e33935.

Wang T, Husain M (2014) The expanding repertoire of the IL-12 cytokine family in teleost fish: Identification of three paralogues each of the p35 and p40 genes in salmonids, and comparative analysis of their expression and modulation in Atlantic salmon Salmo salar. Dev Comp Immunol 46:194-207.

Watford WT, Moriguchi M, Morinobu A, O’Shea JJ (2003) The biology of IL-12: coordinating innate and adaptive immune responses. Cytokine Growth Factor Rev 14: $361-368$

Zhang S, Wang Q (2008) Factors determining the forma- 


\section{J-a Hwang, JE Kim, H-s Kim, J-H Lee}

tion and release of bioactive IL-12: regulatory mechanisms for IL-12p70 synthesis and inhibition. Biochem Biophys Res Commun 372:509-512.

Zhao XJ, Liu ZZ, Li XS, Wang Y, Wang CH (2012) Major histocompatibility complex class II B allele polymorphism and its association with resistance/susceptibility to Aeromonas hydrophila in the "whole white" color pattern of Cyprinus carpio var. color. J Fish Sci China 19:399-407. 